УДК 615.32:582.998.1.794.1`2

ВОЗМОЖНОСТЬ ИСПОЛЬЗОВАНИЯ ЛЕКАРСТВЕННОГО РАСТИТЕЛЬНОГО СЫРЬЯ ПРИ ЛЕЧЕНИИ ОНКОЛОГИЧЕСКИХ ЗАБОЛЕВАНИЙ

\author{
Т.С. Гончарова, С.П. Лукашук
}

Пятигорский медико-фармацевтический институт - филиал ГБОУ ВПО ВолгГМУ

Минздрава России, г. Пятигорск

\title{
POSSIBILITY OF PLANTS ACTIVE PARTS USAGE FOR ONCOLOGICAL DISEASES TREATMENT
}

\section{T.S. Goncharova, S.P. Lukashuk}

Pyatigorsk Medical and Pharmaceutical Institute - a branch of Volgograd State Medical University, Pyatigorsk

$$
\text { E-mail:russafina@mail.ru }
$$

Статья посвящена применению лекарственных растительных средств в лечении онкозаболеваний. Особое внимание обращается на многокомпонентный сбор нового состава, обладающий антиэметическим действием. На основе проведенного анализа и данных ФС установлен химический состав фитосбора, его терапевтическое действие и предполагаемая результативность при одновременном применении с основной терапией онкологического заболевания.

Ключевые слова: мята перечная, мелисса лекарственная, ромашка аптечная, моноклональные антитела, онкологические заболевания, антиэметическое действие.

В настоящее время злокачественные опухоли занимают одно из первых мест по уровню заболеваемости и смертности. Ежегодно регистрируется 10 млн новых случаев рака, поэтому создание новых и эффективных средств борьбы с ним - одна из главных задач фармации и медицины. Основными методами лечения рака являются операционная, химио- и лучевая терапия. Часто возникающим побочным эффектом при данных методах лечения является тошнота, поэтому целью исследования стало создание нового
The article describes an implementation of plant drugs for oncological diseases treatment. It focuses on multicomponent combination herbal medicinal preparation, its therapeutic action, and supposed efficiency during its implementation with basic therapy for oncological disease.

Keywords: Mentha piperita, Melissa officinalis, Matricaria chamomilla, monoclonal antibodies, oncological diseases, antiemetic action.

лекарственного растительного средства с противорвотной активностью.

Фитопрепараты пока не нашли широкого применения в данной области, хотя их цитостатическая и противоопухолевая активность доказана. Уже получают противоопухолевые препараты из барвинка, безвременника, тисса тихоокеанского, аира, подорожника, календулы, омелы и др. Актуальность использования растительных препаратов заключается в том, что они малотоксичны, редко оказы- 
вают побочные воздействия на организм больного, имеют низкую стоимость.

Цель исследования: создание многокомпонентного сбора оптимального состава из листьев мяты перечной, мелиссы лекарственной и цветков ромашки аптечной, обладающего антиэметическим действием; стандартизация.

Кроме того, рассматривается совместное применение предлагаемой фитокомпозиции с терапией моноклональными антителами (МАТ), которые сделали противоопухолевую терапию более эффективной и менее токсичной. Если традиционная химиотерапия - это «ковровое бомбометание», при котором поражаются и здоровые клетки, то иммунотерапия МАТ - это «точечные удары», направленные против белковых молекул в опухолевых клетках.

Лекарственное растительное сырье: листья мяты перечной, листья мелиссы лекарственной, цветки ромашки аптечной. Количественное определение эфирного масла в лекарственном растительном сырье проводили методом по ГФ $\mathrm{XI}[1]$.

В результате проведенных исследований впервые был разработан сбор, состоящий из листьев мяты перечной, мелиссы лекарственной и цветков ромашки аптечной, обладающий противорвотной активностью, и предложено его совместное применение с терапией МАТ.

В процессе исследования химического состава предлагаемого сбора была проведена стандартизация по ФС «Сборы» и определено количественное содержание БАВ (эфирных масел) методом 1 ГФ XI [1]. Для определения подлинности сбора были выявлены внешние и микроскопические признаки входящих в него компонентов. Проверены критерии качества сбора по товароведческим показателям и содержанию ведущей группы БАВ.
Для обозначения значимости исследования целесообразно рассмотреть применение сбора на фоне одного из наиболее распространенных онкозаболеваний - рака молочной железы (РМЖ), для терапии которого наиболее часто используется «Трастузумаб» [4]. Он включает в себя производные ДНК, рекомбинантные гуманизированные МАТ против HER2 -рецепторов, принадлежащих к рецепторам эпидермального фактора роста. Усиленная экспрессия HER2 в ткани рака молочной железы обнаруживается у 20-30\% больных. Она сопровождается резким снижением апоптоза, усилением пролиферации, уменьшением числа рецепторов эстрогенов в опухоли и снижением, а зачастую и отсутствием эффективности химио- и эндокринотерапии. «Герцептин» блокирует пролиферацию, «включает» апоптоз клеток-мишеней и обладает антиангиогенной активностью.

Необходимо отметить, что МАТ, несмотря на большую эффективность и безопасность, не полностью заменили традиционные методы лечения рака.

Лечение «Трастузумабом» в сравнении с другими видами терапий РМЖ является более «мягким», так как побочные эффекты выражены слабо или в умеренной степени [3].

Широко используемыми средствами для устранения тошноты в онкологии являются препараты «Ондансетрон» (умеренная степень) и «Метоклопрамид» (легкая степень тяжести).

Вместо данной группы ЛП в исследовании предлагается возможность использования ЛРС, в частности, данной фитокомпозиции, обладающей противорвотной активностью и состоящей из листьев мяты перечной, листьев мелиссы лекарственной и цветков ромашки аптечной. 


\section{Библиографический список}

1. Государственная фармакопея СССР. Вып. 1: Общие методы анализа / МЗ СССР 11-е изд. - М.: Медицина, 1987. - С.266-267; 290-299.

2. Джонстон Р. Апоптоз: связь между раком генетики и химиотерапии // Cell. - 2002 №108. - С. 153-164.

3. Миллер К. Используя признаки рака: будущее завоевание рака молочной железы // Европейский журнал рака. - 2003. - Т. 39, №12. - С. 1668-1675.

4. Физическая активность и риск развития рака молочной железы у женщин в возрасте 20 - 54 лет / Дж. Верлоп, М.А. Рокус, ван дер Кук и др. //J. Natl. Cancer Inst. 2000. - № 92. - C. 128-135.

Гончарова Татьяна Сергеевна - студентка Пятигорского медикофармацевтического института - филиала ГБОУ ВПО ВолгГМУ Минздрава России. Область научных интересов: фармакогнозия, технология лекарств. E-mail: russafina@mail.ru.

Лукашук Светлана Павловна - кандидат фармачевтических наук, дочент кафедpы фармакогнозии Пятигорского медико-фармацевтического института - филиала ГБОУ ВПО ВолгГМУ Минздрава России. Область научных интересов: изучение лекарственных растений семейства барбарисовых. E-mail: svetalukashuk@inbox.ru 